\title{
Fraud Diamond Theory in Detecting Financial Reporting Manipulation: A Case of Mining Companies Listed on the Indonesia Stock Exchange
}

\author{
1* Mafudi, ${ }^{1}$ Atiek Sri Purwati, ${ }^{1}$ Agung Praptapa, ${ }^{1}$ Sugiarto, ${ }^{1}$ Yonatan Daya Persada \\ ${ }^{1}$ Accounting Department, Universitas Jenderal Soedirman \\ Purwokerto, Indonesia \\ * Correspondence Author: mafudibbs12@gmail.com
}

Received: February 17, 2021. Revised: April 9, 2021. Accepted: April 12, 2021. Published: April 16, 2021.

\begin{abstract}
Forensic accounting helps auditor in collecting information while conducting necessary assessment to discover fraud practice. One popular theory in the field is the fraud diamond theory. This study implements the theory to detect the existence of financial statement fraud on mining sector in Indonesia. The diamond fraud model as the enhancement of the triangle theory of fraud concerns budget priorities, financial stability, inefficient monitoring, adjustments to the auditor and changes to the manager. As a dependent variable, financial statement manipulation funded by income control is used. The sampling of 9 companies listed on the Indonesian Stock Exchange in the mining sector in 2017-2019 was chosen using purposeful sampling methods, resulting in 27 data observations. The data testing was performed by a multi-linear regression method. This study showed that financial targets and financial stability affect the occurrence of fraud in financial reports. Simultaneously, insufficient monitoring, auditing and change of the director have no impact on the financial statements.
\end{abstract}

Keywords: financial statement fraud, fraud diamond

\section{INTRODUCTION}

Financial Statement Fraud is a form of a fraudulent act. Fraud is an act committed by a person in an organization to take advantage of himself or a group of people. Herawati (2013) defines fraud as "an arrangement of irregularities and illegal acts which is a trick carried out for the benefit or loss of the organization, which is committed by people outside or within the organization". According to the Treadway Commission (Hasnan, Suhaily, Rashidah Abdul Rahman, \& Sakthi Mahenthiran, 2013), financial reporting fraud is defined as "an act of deliberate deviation against company records such as errors in applying accounting principles, which result in materially misleading reports". The misrepresented information is either an oversight or a deliberate attempt to misinterpret the business's actual economic and financial health. Income is improperly administered whether the financial statements are unfairly governed or viewed outside the legal system (Kaya \& Turegun, 2017; Svabova, Kramarova, Chutka, \& Strakova, 2020). 
Wells (2011) states that fraud can include any or a portion of the financial reporting processes. These may be generated by managers, who are concerned with performance, such as income, and to hide the firm's true efficiency. The fraud often targets executive pay, compensation, and equity holdings. There are stories of trustworthy companies involved in fraudulent reporting (Martin \& Junior, 2020). Fraudulent reporting has resulted in substantial losses as seen in table 1 .

Tabel 1

Total losses and percentage of fraud

\begin{tabular}{lcccccc}
\hline \multirow{2}{*}{ Type of fraud } & \multicolumn{2}{c}{2012} & \multicolumn{2}{c}{2014} & \multicolumn{2}{c}{2016} \\
\cline { 2 - 7 } & US Dollar & $\%$ & US Dollar & $\%$ & US Dollar & $\%$ \\
\hline $\begin{array}{l}\text { Misappropriation of } \\
\text { assets }\end{array}$ & 120.000 & 86,7 & 130.000 & 85,4 & 125.000 & 835 \\
\hline Dishonesty & 250.000 & 33,4 & 200.000 & 36,8 & 200.000 & 35,4 \\
\hline Information asymmetry & 1.000 .000 & 7,6 & 1.000 .000 & 9,0 & 975.000 & 9,6 \\
\hline
\end{tabular}

Source: ACFE Report to Nations in 2016

In Indonesia fraud involving financial statements have occurred, and large companies such as PT Ancora Mining Service were involved (Pristine, 2011). The scandal stemmed from the financial institution's accounting practices that helped them to minimize taxes. The case demonstrates the ineffectiveness of auditing to deter fraud and the lack of effectiveness of financial reporting. Also, a false financial reporting by PT Timah. PT Timah was accused of falsely certifying a financial report for the first semester of fiscal 2015. This fraudulent financial report was intended to cover up the ongoing poor results of PT Timah (Afrianto, 2016).

Spathis (2002) offers details on the key cause factors that can be used in deception on company financial statements. People who are aware of their risk for being captured are more likely to be caught (Kranacher et al. (2011). This article illustrates fraud vulnerabilities inherent in businesses. Fraud Diamond needs motivation, rationalization, capability, and pressure. Fraud Diamond is the synthesis of an incentivized scenario, motivation, and rationalization. The mining sector is, in fact, the second-lowest sector that has encountered fraud cases relative to other sectors. Despite being extremely costly and dangerous, the degree of fraud is small. Therefore, this industry is attractive to study.

The objectives of this study are to find out the effect of financial targets, financial stability, effective monitoring and change of auditors on the occurrence of fraudulent financial reporting in the Indonesian mining companies in 2017-2019.

\section{DATA AND METHODOLOGY}

This research is a quantitative study that emphasizes on testing theories through measuring variables with numbers and analyzing data using multiple regression analysis using SPSS.

The study population is public companies in the mining company category listed on the Indonesia Stock Exchange (IDX) during the 2017-2019 period. The sampling technique used was purposive sampling with specific criteria as follows: first, mining companies that consecutively published their audited annual report in 2017-2019; second, the company has information concerning the variables under study

There were 44 mining companies that were consistently listed on the IDX for the 
2017-2019 period and published financial reports consecutively during the study period. Nine companies met the criteria. However, 35 of them did not meet both criteria leave only nine companies for analysis. Nine companies for three years made up to 27 observations. The data was then analysed using statistical analysis were used: descriptive statistics, classical assumption test, multiple Linear Regression Analysis.

\section{RESULTS}

\section{A. Descriptive Statistical Analysis}

The descriptive statistical analysis of the data collected for all variables can be seen in Table 2. The vector Y (fear of the financial statements) has an average value of -0.243 , meaning that mining firms have committed fraud in the financial statements with a trend of growing income with a minimum value of -0.228 and a maximum value of 0.082 on average. A standard deviation that exceeds the average value indicates high fluctuations in the variable financial statement fraud data during the observation period.

Financial targets (X1) are the amount of profit the company must achieve. Based on table 2, it is known that the average X1 mining company is -0.25 with a lower score of -1.571 and a maximum value of 0.196 with a standard deviation of 0.300 from the average. The standard deviation value that exceeds the average value indicates the high fluctuation of the financial targets (X1) variable data during the observation period.

Descriptive Statistics

\begin{tabular}{|l|r|r|r|r|r|}
\hline & $\mathrm{N}$ & \multicolumn{1}{|c|}{ Minimum } & \multicolumn{1}{c|}{ Maximum } & \multicolumn{1}{c|}{ Mean } & \multicolumn{1}{c|}{ Std. Deviation } \\
\hline Y & 30 & -.2285571000 & .0820562300 & -.024390888216 & .0792109392729 \\
X1 & 30 & -1.5714928000 & .1962258400 & -.025798676763 & .3001746746069 \\
X2 & 30 & -.6144488500 & 1.5028658000 & .118244044323 & .3362085206300 \\
X3 & 30 & .20000000 & .50000000 & .3833333367 & .09160133325 \\
X4 & 30 & 0 & 1 & .10 & .305 \\
X5 & 30 & 0 & 1 & .47 & .507 \\
Valid N & 30 & & & & \\
(listwise) & & & & & \\
\hline
\end{tabular}

Table 2 Result of Descriptive Statistical Analysis

Source: Processed secondary data

Financial stability (X2) is a condition that illustrates an organization's financial position in a stable state. The average X2 mining enterprise is considered to be 0.118 based on Table 2, with a value of at least 0.614 and a maximum value of 1.502 , with an average standard deviation of 0.336 . Standard deviation value that exceeds the average value indicates a high fluctuation in financial stability (X2) variable data during the observation period.

The phenomenon of fraud is one of the consequences of inadequate oversight or control to provide agents or supervisors with an ability to perform defiantly by committing fraud in financial reports. Ineffective monitoring (X3) in table 4 has an average of 0.383 with the lowest value of 0.200 and a maximum value of 0.500 . $\mathrm{X} 3$ has a standard deviation of 0.091, which is smaller than the average, which implies that effective monitoring is around the mean value.

\section{B. Multiple Regression Analysis}

The regression analysis used in this study to evaluate the hypothesis consists of a change of director (DCHANGE), financial stability (ACHANGE), effective monitoring (BDOUT), financial goals (ROA) and change of auditors (AUDCHANGE) for 2017-2019 mining company financial statements fraud. Table 
3 shows the findings of the Multiple

Regression Analysis.

Table 3 The Results of Multiple Regression Analysis

Coefficients $^{\mathrm{a}}$

\begin{tabular}{|c|c|c|c|c|c|c|}
\hline \multirow{2}{*}{\multicolumn{2}{|c|}{ Model }} & \multicolumn{2}{|c|}{ Unstandardized Coefficients } & $\begin{array}{l}\text { Standardized } \\
\text { Coefficients } \\
\end{array}$ & \multirow[b]{2}{*}{$\mathrm{t}$} & \multirow[b]{2}{*}{ Sig. } \\
\hline & & B & Std. Error & Beta & & \\
\hline \multirow[t]{6}{*}{1} & (Constant) & .150 & .056 & & 2.657 & .015 \\
\hline & Financial Targets & .119 & .056 & .470 & 2.134 & .045 \\
\hline & Financial Stability & .216 & .051 & .962 & 4.260 & .000 \\
\hline & $\begin{array}{l}\text { Ineffective } \\
\text { Monitoring }\end{array}$ & -.480 & .146 & -.533 & -3.280 & .004 \\
\hline & Change in Auditor & -.051 & .038 & -.208 & -1.351 & .191 \\
\hline & Change in Manager & -.015 & .026 & -.094 & -.566 & .577 \\
\hline
\end{tabular}

a. Dependent Variable: Y

\subsection{Hypothesis Testing}

In this article, the hypothesis utilizing Ttest (partial). The T-test indicates whether the dependent variable is influenced partly by the independent variable. This research applies a two-way research hypothesis.

a. Hypothesis testing $1(\mathrm{H} 1)$.

The first hypothesis implies that financial targets (ROA) influence manipulation in financial statements (earnings management). The test results for hypothesis 1 suggest that the $t$-value of the variable financial targets (ROA) is 2.134, whereas the t-table value is 0.68581 with $\alpha=0.05$ and $\mathrm{df}(\mathrm{n}-\mathrm{k}) 27-5=$ 22. Based on these observations, it can be shown that the t-count is greater than the value of the t-table (2.134>0.068581), so it can be inferred that fraud of financial statements caused by variable financial objectives (ROA). Hypothesis 1 (H1), which notes that financial priorities affect fraud in financial statements, is therefore acknowledged.

b. Hypothesis testing $2(\mathrm{H} 2)$
The second hypothesis notes that financial stability (ACHANGE) influences fraud in financial statements (earnings management). The test results for hypothesis 2 reveal that the calculated $t$ of the variable financial stability (ACHANGE) is 4.260 , where 0.68581 is the t-table value with alpha $=0.05$ and $\mathrm{df}$ $(\mathrm{n}-\mathrm{k}) \quad 27-5=22$. Based on these observations, it can be shown that the tcount is higher than the t-table value $(4,260>0.068581)$, it can be implied that fraud of financial statements is caused by variable financial targets (ROA). Therefore, Hypothesis 2 (H2), which states that financial stability affects financial statement fraud is accepted.

c. Hypothesis testing $3(\mathrm{H} 3)$

The third hypothesis notes that efficient monitoring (BDOUT) influences fraud in financial statements (earnings management). The testing results for hypothesis 4 show that the t-count value of the effective monitoring variable (BDOUT) is -3.280, while the t-table value with $\alpha=0.05$ and $\mathrm{df}(\mathrm{n}-\mathrm{k}) 27-5=22$ 
is 0.68581 . Based on these results, it can be seen that the $\mathrm{t}$-count is smaller than the t-table value $(-3.280<0.68581)$; therefore, it can be inferred that the efficient monitoring factor does not impact the fraud of financial reports. On this premise, Hypothesis 3 (H3), which states that ineffective monitoring influences financial statements fraud, is rejected.

d. Hypothesis testing $4(\mathrm{H} 4)$

The fourth hypothesis states that change in auditor (AUDCHANGE) affects financial statement fraud (earnings management). The testing results for hypothesis 4 show that the t-value of the variable change in auditor (AUDCHANGE) is -1.351 while the $\mathrm{t}$ table value with $\alpha=0.05$ and df (n-k) 27$5=22$ is 0.68581. Based on these findings, it can be shown that the t-count is lower than the t-table value $(-1.351$ $<0.68581$ ), and it can be implied that the auditor's variable adjustment does not impact the fraud of the financial statements. On this premise, Hypothesis 4 (H4), which implies that the auditor's amendment affects fraud in financial statements, is rejected.

e. Hypothesis testing 5 (H5)

The fifth hypothesis states that change in director (DCHANGE) affects financial statement fraud (earnings management). The testing results for hypothesis 5 show that the t-count value of the variable change in director (DCHANGE) is -0.566 , while the t-table value with $\alpha=0.05$ and df (n-k) $27-5=22$ is 0.68581. Based on these results, it can be identified that the tcount is lower than the value of the t-table $(-0.566<0.68581)$, thus, it can be stated that the adjustment in the director variable has no impact on the fraud of the financial statement. Hypothesis 5 (H5) therefore notes that the change in director influences fraud in financial statements is denied.

\section{DISCUSSION}

A. The Effect of Financial Targets on Financial Statement Fraud

Based on the results of financial targets measured using ROA, financial targets affect financial statement fraud. Therefore, the higher the company's financial target, seen from the increase in ROA, will encourage the company to commit fraud by committing financial statement fraud. Pressure, which is one of the diamond theory fraud factors, can be detected by this variable. Excessive pressure on management to achieve the financial targets set by the directors triggered earnings management. These results are consistent with Widyastuti (2009) research, which argues that companies that have large profits (measured using ROA) are more likely to perform earnings management than companies with low profits. The research results by Norbarani (2012), Nugraha \& Henny (2015) also show the same results, financial targets that are proxied by ROA influence the occurrence of financial statement fraud.

\section{B. The Effect of Financial Stability on Financial Statement Fraud}

As determined by the total asset turnover ratio, financial stability influences the fraud in financial statements based on the results. Martantya \& Daljono (2013), who states that management is always under pressure to display whether the firm can use its assets properly to produce income, supports this outcome. Management commits fraud using financial reports as a means of covering up the company's dire financial condition. Excessive pressure on management is conforming with the fraud diamond theory of pressure. One way is to change the appearance of the total assets to their liking. Companies manipulate income whenever their performance is threatened by financial stability or economic conditions. The percentage change in total assets indicates fraudulent financial statements. A study by Skousen et al. 
(2009), Martantya \& Daljono (2013), Sihombing (2014), and Tessa \& Harto (2016), who previously found that financial stability induces fraud in financial reports, also confirm the findings of this article.

\section{The Effect of Ineffective Monitoring on Financial Statement Fraud}

As calculated by the structure of the independent board of commissioners, ineffective monitoring does not impact financial statement fraud based on the research findings. A fraud diamond component is an opportunity detected through insufficient monitoring and was not proved in this analysis. Opportunities can occur because of weak internal controls, poor management oversight, or through the use of positions. The board's role in carrying out the supervisory function of the company's operations has not been running correctly, and the appointment and presence of the board of commissioners may only be made to fulfil company regulations. This result is supported by Norbarani (2010), Molida (2011), Prasastie (2015), Pardosi (2015), who in their research concluded that independent commissioners did not affect financial statement fraud.

\section{The Influence of Change in Auditor on Financial Statement Fraud}

Rationalization is one of the most challenging elements of the fraud diamond to measure, according to No. SAS 99, rationalization can be measured by the auditor change cycle (change in auditor). Based on research findings, change in auditor does not influence financial statement fraud. It is because many companies in this study did not change auditors during the 2017-2019 period. Additionally, the small number of companies studied in this study induced a lack of data analyzed so that the measurement results were less than optimal.
E. The Influence of Change in Director on Financial Statement Fraud

Capability, one of the elements in the fraud diamond theory, can be explained through the change of director. Frauds that generally large in number are not possible if there is no person with superior capabilities. Characteristics related to capabilities include position, understanding, and ego. Based on the research results, change in director does not influence financial statement fraud. Many companies in this study did not change their directors during the 20172019 period, and less than 30 observational data that was studied produced the results of this study to be less than optimal. Contrarily, Wolfe \& Hermanson (2014) argued that capability is one of the factors that influence fraud and changes in directors, indicating that fraud.

\section{CONCLUSION AND IMPLICATION}

Based on the outcome of the research and discussion, the following conclusions are drawn:

a. Financial targets influence financial statement fraud.

b. Financial stability affects financial statement fraud.

c. Ineffective monitoring does not affect financial statement fraud.

d. Change in auditor does not affect financial statement fraud.

e. Change in director does not affect financial statement fraud.

Based on the results as mentioned earlier, the study recommends the following:

First, this research leads to the theory of fraud diamond (Wolfe and Hermanson, 2004). This study further reinforces the notion that financial targets and financial stability could be used for fraud in financial reports. Investors are expected to understand variable financial targets and financial stability better so that this research can be used as an early detection tool for detecting fraud in the company's 
financial statements to make effective decisions.

Second, for the advancement of scientific accounting knowledge, this study may provide an overview of variable financial targets and financial stability that affect financial statements fraud and may elucidate the concept of financial targets and financial stability of fraud diamonds to identify financial statements fraud. This study is expected to become an encouragement for further studies for other parties.

\section{REFERENCES}

[1] ACFE (Association of Certified Fraud Examiners). 2016. Report to Nations: On Occupational Fraud and Abuse. ACFE. Amerika.

[2] Afrianto, Dedy. 2016. Timah's Board of Directors accused of financial statement manipulation. http://economy.okezone.com/read/201 6/01/27/278/1298264/direksi-timahdituding-manipulasi-laporan-keuangan, accessed (in Bahasa) 15 August 2017, at 18.20

[3] Hasnan, Suhaily., Rashidah Abdul Rahman., \& Sakthi Mahenthiran. 2013. Management Motive, Weak Governance, Earnings Management, and Fraudulent Financial Reporting. Journal of International Accounting Research. Vol. 12 No. 1, pp 1-27.

[4] Herawati, Evy. 2013. The Influence of the Professionalism of the Internal Auditor on Asset Misappropriation (Survey on the Internal Auditor Headquartered in Bandung). Journal of Accounting Universitas Pendidikan Indonesia. Vol. 4 No. 1, pp 8-16

[5] Kaya, C. T., \& Turegun, N. (2017). Associations between earnings management manipulation types and debt contracts, political costs and characteristics of board of directors. International Journal of Academic Research in Accounting, Finance and Management Sciences, 7(2). doi: 10.6007/IJARAFMS/v7-i2/2995.

[6] Kranacher, Mary-Jo, Richard A. Riley, jr., dan Joseph T. Wells. 2011. Forensic Accounting and Fraud Examination. John Wiley and Sons, Inc. USA

[7] Martantya, Daljono. 2013. Fraud Detection of Financial Statements through Pressure and Opportunity Risk Factors (Case Study of Companies Receiving Sanctions from Bapepam 2002-2006). Journal of Accounting. Vol. 2 No. 2, pp. 1-12

[8] Martins, O. S., \& Junior, R.P. (2020), The Influence of Corporate Governance on the Mitigation of Fraudulent Financial Reporting Orleans, Review of Business Management, 22(1), p. 65-84 DOI:10.7819/rbgn.v22i1.4039

[9] Molida, Resti. 2011. Financial Stability Analysis, Personal Financial Need and Ineffective Monitoring on Fraud Financial Statement in the Fraud Triangle Perspective (in Bahasa). Journal of Accounting. Universitas Diponegoro. Semarang.

[10] Nugraha, N.D.A., \& D. Henny, 2015, Detection of Financial Statements through Risk, Pressure and Opportunity Factors (Based on the OJK Press Release 2008-2012) (in Bahasa), Trisakti e-Journal, Vol. 2. No. 1. pp 29-48.

[11] Norbarani, Listiana. 2012. Financial Statement Fraud Detection with Fraud Triangle Analysis Adopted in SAS No. 99. Financial Statement Fraud (in Bahasa). Diponegoro Journal of Accounting. Vol. 5 No. 2, pp 21-33 
[12] Pardosi, Rica Widia. 2015. Diamond Fraud Analysis in Detecting Fraud Financial Reports on Manufacturing Company in Indonesia by Using Fraud Score Model (in Bahasa). Financial Statement Fraud. Diponegoro Journal of Accounting. Vol. 6 No. 3, pp 15-27

[13] Prasastie, Agung. 2015. Analysis of Factors Affecting Fraud Financial Statements with a Diamond Fraud Perspective (Empirical Study of LQ 45 Companies Listed on the IDX in 20092013) (in Bahasa). Journal of Accounting, Faculty of Economics and Business, University of Lampung. Bandar Lampung.

[14] Pristine, Shally. 2011. Strange Financial Report, Ancora Mining Service Reported to the Directorate General of Taxes (in Bahasa). http://m.republika.co.id/berita/breaking -news/hukum/11/01/11/157626laporan-keuangan-aneh-ancoramining-service-dilaporkan-ke-ditjenpajak, accessed on 16 August 2017, at 04.47

[15] Sihombing, Kennedy Samuel \& Shiddiq Nur Rahardjo. 2014. Diamond Fraud Analysis in Detecting Fraud Financial Statement (in Bahasa). Diponegoro Journal of Accounting. Vol. 3 No. 2, pp 1-12

[16] Skousen, C.J., K. R. Smith, \& C. J. Wright. 2009. Detecting and Predicting Financial Stability: The Effectiveness of the Fraud Triangle and SAS N0.99, Journal of Accounting and Auditing. SSRN (Social Science Research Network), Vol. 13, pp. 53-81.

[17] Spathis, T. Charalambos. 2002. Detecting False Financial Statements Using Published Data: Some Evidence from Greece. Managerial Auditing Journal, Vol.17 No. 4, pp. 179-191.

[18] Svabova, L., Kramarova, K., Chutka, J., \& Strakova, L. (2020). Detecting earnings manipulation and fraudulent financial reporting in Slovakia. Oeconomia

Copernicana, 11(3), 485-508. https://doi.org/10.24136/oc.2020.020

[19] Tessa, Chyntia G. \& Puji Harto. 2016. Fraudulent Financial Reporting: Testing the Pentagon's Fraud Theory in the Financial and Banking Sector in Indonesia (in Bahasa). Journal of Accounting. Universitas Diponegoro, Semarang. The paper was presented at the XIX National Accounting Symposium. Lampung.

[20] Wells, J. T. (2011). Corporate fraud handbook: prevention and detection. 3 ed. New Jersey: Wiley

[21] Widyastuti, Tri. 2009. The Influence of Ownership Structure and Financial Performance on Earnings Management: A Study on Manufacturing Companies on the IDX (in Bahasa). Master's Journal of Accounting. Vol. 9 No. 1, pp. 30-41.

[22] Wolfe, D. T. and Hermanson, D. R. (2004). "The fraud diamond: Considering the four elements of fraud". The CPA Journal, December, pp.1-5.

\section{Creative Commons Attribution License 4.0 (Attribution 4.0 International, CC BY 4.0)}

This article is published under the terms of the Creative Commons Attribution License 4.0 https://creativecommons.org/licenses/by/4.0/deed.en_US 